\title{
Did the Solar Eclipse of 9 March 2016 Attract Tourist to Come to Indonesia?
}

\author{
Nuria Haristiani ${ }^{1}$, Ani Siti Wiryani ${ }^{2}$, Arvina Rusli ${ }^{2}$, Asep Bayu Dani Nandiyanto ${ }^{2 *}$, \\ Novie Permatasari ${ }^{2}$, Transmissia Noviska Sucahya ${ }^{2}$, Anisa Purnamasari ${ }^{2}$, Desri Sofiani ${ }^{2}$, Isma \\ Widiaty $^{3}$, Ade Gafar Abdullah ${ }^{4}$, Ana $^{3}$, Ratih Hurriyati ${ }^{5}$ \\ ${ }^{1}$ Departemen Pendidikan Bahasa Jepang, Universitas Pendidikan Indonesia, Jl. Dr. Setiabudi 229, \\ Bandung 40154, Indonesia \\ ${ }^{2}$ Departemen Kimia, Universitas Pendidikan Indonesia, J1. Dr. Setiabudi 229, Bandung \\ 40154, Indonesia \\ ${ }^{3}$ Departemen Pendidikan Kesejahteraan Keluarga, Universitas Pendidikan Indonesia, J1. Dr. Setiabudi \\ 229, Bandung 40154, Indonesia \\ ${ }^{4}$ Departemen Pendidikan Teknik Elektro, Universitas Pendidikan Indonesia, J1. Dr. Setiabudi 229, \\ Bandung 40154, Indonesia \\ ${ }^{5}$ Departemen Manajemen dan Bisnis, Universitas Pendidikan Indonesia, Jl. Dr. Setiabudi 229, \\ Bandung 40154, Indonesia
}

\begin{abstract}
Solar eclipse phenomenon is one of the spectacular events in nature. On 9 March 2016, the solar eclipse happened in several regions in Indonesia. This event attracted tourists to visit Indonesia. The tourists came for not only seeing the beautiful solar eclipse scene but also getting sensation of myths and cultures in Indonesia during the solar eclipse. Here, the aim of this study was to discuss about the effects of solar eclipse event on the increases in the number of tourists to Indonesia and influence of foreign exchange in Indonesia. Research methodology used in this study was a literature study comparing to statistical data of a number of tourists who come to Indonesia. To investigate about myths in Indonesia, we took literature study by collecting information from international journals relating to myths in Indonesia. Afterwards, to investigate the tourist effect on economy of Indonesia, we used data from Indonesian Central Bureau of Statistics about hotel occupancy and exchange rate . The data was also compared to the economic data (before and after total solar eclipse occur). In conclusion, although ancient people agree that the solar eclipse is a dangerous event, the modern people think that the event is one of the spectacular phenomena. Combination of beautiful nature with myths and cultures in Indonesia attracted more tourists to visit Indonesia. Indeed, the event gave beneficial points for Indonesian people because tourists gave a financial advantage to local people. Thus, the long-term goal is to give information that Indonesian people must be able to take chance the natural wealth of Indonesia to attract tourists to improve the local economy in Indonesia.
\end{abstract}

Keywords: eclipse; myth; science; tourist;economy

\section{INTRODUCTION}

Solar eclipse phenomenon is a rare event that happens in the universe. This phenomenon occurs when the Sun and the Moon are in a line in a few minutes, so that sunlight is covered by the Moon, resulting the darkening sky. (Fabian, Winterhalter, \& et al, 2001; Foken, Wichura, \& et al, 2001; Nishanth, Ojha, \& et al, 2011) This eclipse takes place in several phases: (i) the first contact, when the Moon began to cover the Sun's edge; (ii) the second contact, when almost the entire disk of the Moon covered the Sun; (iii) the maximum eclipse, when the disk of the Sun is covered entirely by the Moon, the distance between the two discs is very small; (iv) the third contact, when the Moon starts to release from the Sun, and the maximum eclipse phase has been completed; and (v) the fourth phase, when the Moon starts to go from the Sun. The solar eclipse phenomenon of this phase has been completed. (Tiwari, N. K. 2015). Most ancient Indonesian people believe myths during the solar eclipse. The pre-Islamic Javanese people believed that during the solar eclipse, Batara Kala swallows the Sun because of his anger. (Keeler, W. 1988; Wirahmihardja, S. D. 2014). Therefore, people are prohibited from conducting activities, especially activities that were considered as taboos. Pre-Islamic Javanese people believed that during the progress of solar eclipse, pregnant women and children should hide inside the house to avoid anger of Batara Kala. They also believed that 
during the solar eclipse, people should not do these activities, such as building a house, eating, hosting a wedding party, and looking at the Sun directly. Further, they believed that these following activities should be conducted, such as cleaning the house and belongings heritage during the solar eclipse phenomenon.

On 9 March 2016, the solar eclipse phenomenon occurred in several regions in Indonesia (see Table 1). Total solar eclipse happens in Palembang (South Sumatra), Bangka Belitung, Sampit and Palangkaraya (Central Borneo), Balikpapan (East Borneo), Palu, Poso, Luwuk (Central Sulawesi), Ternate and Halmahera (North Maluku), West Sulawesi, Bengkulu, Jambi and West Borneo. Whilest, some locations in Indonesia experienced partial solar eclipse phenomenon, such as Padang (West Sumatra), Jakarta, Bandung, Surabaya, Pontianak, Denpasar, Banjarmasin, Makassar, Kupang, Manado and Ambon. This phenomenon attracted tourists to visit Indonesia. The reason for visiting Indonesia is not only to see the beauty of the solar eclipse phenomenon, but also to enjoy some myths and indigenous cultures in Indonesia.

Table 1. Solar eclipse data in Indonesia, on March 9, 2016 (Source: BMKG

\begin{tabular}{|c|c|c|c|c|c|}
\hline Site & Province & $\begin{array}{l}\text { Time of } \\
\text { first } \\
\text { contact, } \\
\text { LT }\end{array}$ & $\begin{array}{l}\text { Time of } \\
\text { eclipse } \\
\text { maximu } \\
\text { m, LT }\end{array}$ & $\begin{array}{l}\text { Time of } \\
\text { fourth } \\
\text { contact, } \\
\text { LT }\end{array}$ & $\begin{array}{l}\text { Maximum } \\
\text { obscuration } \\
\text { of solar } \\
\text { disk, \% }\end{array}$ \\
\hline Bandung & West Java & $06: 19$ & $07: 21$ & $08: 32$ & 88.76 \\
\hline Jakarta & DKI Jakarta & $06: 19$ & $07: 21$ & $08: 31$ & 88.76 \\
\hline Padang & $\begin{array}{l}\text { West } \\
\text { Sumatra }\end{array}$ & $06: 21$ & 07:20 & $08: 27$ & 95.41 \\
\hline Surabaya & East Java & $06: 21$ & $07: 25$ & 08:39 & 83.08 \\
\hline Pontianak & West Borneo & $06: 23$ & $07: 27$ & 08:40 & 90.95 \\
\hline Denpasar & Bali & $07: 22$ & $08: 27$ & 09:42 & 76.53 \\
\hline Makassar & $\begin{array}{l}\text { South } \\
\text { Sulawesi }\end{array}$ & $07: 25$ & $08: 34$ & 09:54 & 88.54 \\
\hline Kupang & $\begin{array}{l}\text { East Nusa } \\
\text { Tenggara }\end{array}$ & $07: 28$ & $08: 37$ & $09: 55$ & 65.49 \\
\hline Banjarmasin & $\begin{array}{l}\text { South } \\
\text { Borneo }\end{array}$ & $07: 33$ & 08:30 & $09: 27$ & 98.17 \\
\hline Manado & $\begin{array}{l}\text { North } \\
\text { Sulawesi }\end{array}$ & 07:34 & $08: 29$ & $10: 15$ & 96.66 \\
\hline Ambon & Maluku & 08:33 & 09:29 & $11: 16$ & 86.91 \\
\hline
\end{tabular}

Note: LT is local time

The ancients believed that the solar eclipse is something that is very dangerous because it is loaded with mystical and magical powers. Therefore, they performed various rituals during the solar eclipse to avoid the incoming dangers. However, because of its uniqueness, this ritual is exactly able to attract tourists. In Palembang, a unique tradition during the solar eclipse is done by scrawling face of the child with charcoal to avoid the devil's anger. The Dayak in Borneo believes that during the solar eclipse phenomenon, they must perform rituals, such as: (i) covering their heads to avoid graying, (ii) shaking the tree in order to quickly harvest, and (iii) washing goods heirloom, In addition, the recent Indonesian people, especially Muslims, believe that when the solar eclipse takes place, people should go to the worship and pray to God.

In addition, the solar eclipse of 9 March 2016 coincided with the celebration of Nyepi ritual performed by the Hindu. Many rituals are performed, such as Ogoh-Ogoh and the torch relay festivals. These rituals can attract more tourists to visit Indonesia. Besides, the island of Belitung also presents some interesting destination for the tourists such as Titi Hill, Paramon Hill, Limau Hill, and Samak Hill. On the Titi Hill, while enjoying the solar eclipse phenomenon, tourists can enjoy Malay music and dance performances. Some cities also held festivals to enliven this rare phenomenon. Thus, the interest for the tourists to visit Indonesia increases.

Here, the aim of this study was to discuss about the effects of the solar eclipse event on the increases in the number of tourist to Indonesia and the exchange rate. The longterm goal is to give information that Indonesian people must be able to take chance the natural wealth of Indonesia to attract tourists to improve the local economy in Indonesia.

\section{RESEARCH METHODOLOGY}

To determine the influence of the total solar eclipse phenomenon that occurs in some areas in Indonesia on the arrival of tourists, we analyzed the number of tourists who come to Indonesia, the number of hotel visitors in several cities in Indonesia, and rupiah exchange rate against the US dollar in the early months of 2016. The data were obtained from Badan Pusat Statistik (BPS) and some websites to support our investigation.

\section{RESULTS AND DISSCUSSION}

\subsection{The Number of Tourists}

Table 2 shows the number of foreign tourists in February 2015, January 2016, 
and February 2016 in several airports in Indonesia.

Table 2. Number of Tourist to Visit Indonesia (Source: Badan Pusat Statistik)

\begin{tabular}{|c|c|c|c|c|}
\hline & $\begin{array}{l}\text { Tourists through the } \\
\text { main airport }\end{array}$ & $\begin{array}{l}\text { February } \\
2015\end{array}$ & $\begin{array}{c}\text { January } \\
2016\end{array}$ & $\begin{array}{c}\text { February } \\
2016\end{array}$ \\
\hline 1. & Soekarno-Hatta & 170.741 & 153.503 & 164.317 \\
\hline 2. & Ngurah Rai & 333.072 & 343.663 & 367.024 \\
\hline 3. & Kualamu/Polonia & 18.082 & 10.080 & 14.851 \\
\hline 4. & Batam & 119.642 & 108.888 & 120.351 \\
\hline 5. & Sam Ratulangi & 3.374 & 625 & 1.535 \\
\hline 6. & Juanda & 14.003 & 11.674 & 14.955 \\
\hline 7. & Entikong & 1.873 & 1.050 & 2.307 \\
\hline 8. & Adi Sumarmo & 571 & 465 & 605 \\
\hline 9. & Minangkabau & 2.876 & 3.378 & 3.892 \\
\hline 10. & Tanjung Priok & 6.982 & 5.066 & 6.824 \\
\hline 11. & Tanjung Pinang & 8.023 & 5.971 & 8.407 \\
\hline 12. & BIL & 4.348 & 5.162 & 6.184 \\
\hline 13. & Hasanuddin & 931 & 755 & 876 \\
\hline 14. & Sepinggan & 707 & 656 & 1.150 \\
\hline 15. & Sultan Syarif Kasim II & 2.043 & 1.523 & 1.912 \\
\hline 16. & Adi Sucipto & 5.379 & 6.415 & 7.899 \\
\hline 17. & Husein Sastranegara & 13.008 & 10.964 & 8.402 \\
\hline 18. & Tanjung Uban & 28.977 & 21.484 & 27.642 \\
\hline & Tanjung Balai Karimun & 8.866 & 6.735 & 8.985 \\
\hline & Total & 743.498 & 698.057 & 768.118 \\
\hline
\end{tabular}

From the data, increases in the number of tourist arrivals during the period JanuaryFebruary 2016 were found, in which the increase was about $3.95 \%$. The number of tourists to Indonesia in February 2016 reached more than 768 thousand, and this increased 3.31 percent compared to the number of tourist arrivals in February 2015. In comparison with the number of tourists in Ja nuary 2016, the number of tourists in February 2016 can be classified to be increasing about $10.04 \%$. This indicated that in March 2016, there would be an increase in tourist arrivals due to the solar eclipse phenomenon that occurred in Indonesia as reported on several news. BBC stated about 10,000 foreign tourists and 100,000 domestic tourists had been a witness of the solar eclipse phenomenon (see www.bbc.com/indonesia/berita indonesia/201 6/03/160308_indonesia_gerhana_bisnis). We also found that although Bali is not in the path of the total solar eclipse phenomenon, the number of tourists visiting Bali increased because the solar eclipse phenomenon coincided with the day of Nyepi. Beside Bali, the celebration of Nyepi is also conducted in the city of Palembang (see Figure 1), where the total solar eclipse phenomenon occurs, in which that is the reason for the increasing number of tourists to come Indonesia.

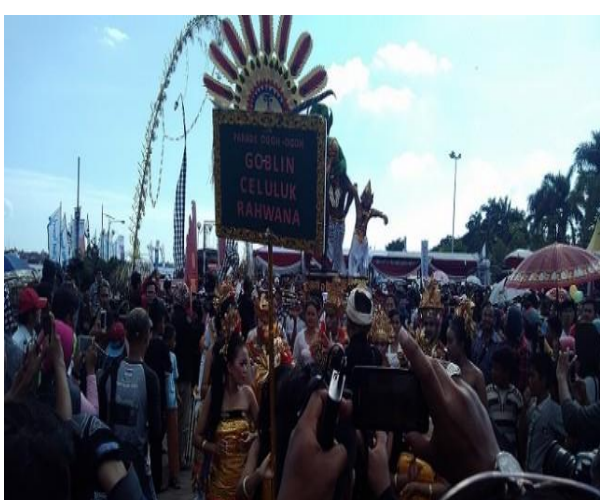

Figure 1. Solar eclipse festival 9 March 2016 at Palembang (Source: vivasumsel.com)

\subsection{Hotel Visitors}

Table 3 shows the number of visitors in 10 provinces in Indonesia. Visitors in some hotels in February 2016 reached about 54.05\%, in which this number was higher (up to 11.47 points) than that in February 2015 (42.58\%). Indeed, compared to the number of hotel visitors in January 2016 that amounted to 42.58\%, hotel visitors in February 2016 could be classified to increase (rose up to 7.76 point). The increasing number also occurs in March 2016 when the solar eclipse phenomenon happened. As reported by Tempo, the Indonesian Hotel and Restaurant Association (IHRA) stated that thousands of hotel rooms in the area of path of the solar eclipse phenomenon were already fully booked. IHRA also estimated that during the past week of eclipse, business hotels throughout Indonesia had reaped a turnover of up to US \$ 10 million (around the Rp 135 billion with exchange rate of $\mathrm{Rp} 13,500$ per US dollar) (see https://m.tempo.co/read/news/2016/03/07/0907 51352/hotel-hotel-di-daerah-gerhana-mataharihabis-dipesan). 
Table 3. The Number of Visitors in Indonesia (Source: Badan Pusat Statistik)

\begin{tabular}{ccccc}
\hline & & \multicolumn{3}{c}{ Hotel Visitor (\%) } \\
\cline { 3 - 5 } No & Province & $\begin{array}{c}\text { Febuary } \\
\mathbf{2 0 1 5}\end{array}$ & January 2016 & February 2016 \\
\hline 1 & West Sumatra & 37,22 & 44,32 & 50,39 \\
2 & Jambi & 33,36 & 34,73 & 54,09 \\
3 & Bengkulu & 47,06 & 55,68 & 59,68 \\
4 & Kepulauan Bangka Belitung & 22,49 & 30,99 & 32,68 \\
5 & DKI Jakarta & 52,32 & 54,44 & 56,15 \\
6 & Bali & 60,03 & 54,38 & 62,46 \\
7 & West Borneo & 45,14 & 44,88 & 55,18 \\
8 & South Borneo & 39,52 & 36,76 & 47,36 \\
9 & North Sulawesi & 45,95 & 63,02 & 64,9 \\
10 & Central Sulawesi & 42,7 & 43,72 & 57,62 \\
\hline & $\mathbf{1 0}$ provinces & $\mathbf{4 2 , 5 8}$ & $\mathbf{4 6 , 2 9}$ & $\mathbf{5 4 , 0 5}$ \\
\hline
\end{tabular}

\subsection{Rupiah Exchange Rate against the Dollar}

Increases in the number of tourists visiting Indonesia due to the solar eclipse phenomenon affects the value of the rupiah against the dollar, according to the statistics shown in Figure 2 (calculated from http://www.xe.com/currencyconverter/).

Figure 2a shows that in May 2015 until July 2015 , the rupiah exchange rate increased from 13,000 to 13,500 rupiah per US dollar. Then, the rupiah increased considerably in August 2015 until September 2015 amounted to 14,500 rupiah per US dollar. However, in October 2015, the rupiah exchange rate decreased of about $10 \%$. Then, the rate increased again in January 2016 to around 13,500 rupiah per US dollar. Figure 2b shows that the rupiah exchange rate in March 2016 to April 2016 was about 12,900 to 13,350 rupiah per US dollar. Indeed, the increases in the rate from March to April 2016 were due to the solar eclipse phenomenon. The more tourists come to Indonesia resulted in the change in exchange rate. This is because tourists bring their money to be consumed in Indonesia.

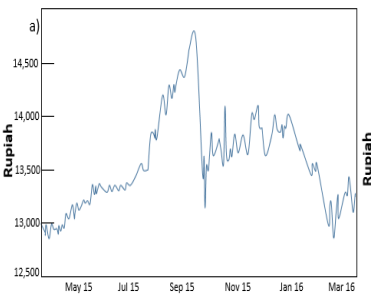

Month

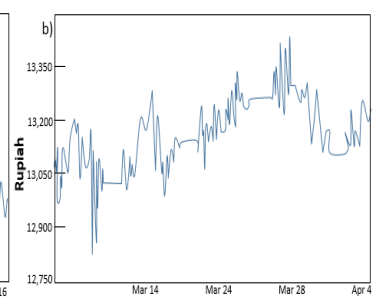

Month
Figure 2. Rupiah exchange rate curve : a) May 2015 - March 2016 , b) March 2016 - April 2016.

\section{Conclusion}

Based on the above data analyses, we conclude that the solar eclipse phenomenon on 9 March 2016 affects the number of tourist arrivals in Indonesia. The number of tourist arrivals and the number of hotel visitors before the solar eclipse day increased. This is due to a variety of festivals and rituals performed by Indonesian people for welcoming the solar eclipse phenomenon. Indeed, the event gives beneficial points for Indonesian people. Therefore, the long-term goal is to give information that Indonesian people must be able to take chance the natural wealth of Indonesia to attract tourists to improve the local economy in Indonesia.

\section{References}

Anonim. (2016, March 8). BBC Indonesia. Retrieved from bbc.com: http://www.bbc.com/indonesia/berita_indonesia/20 $16 / 03 / 160308$ indonesia gerhana bisnis

Aria, P. (2016, March 7). Tempo.Co,Jakarta. Retrieved from Tempo.Co: https://m.tempo.co/read/news/2016/03/07/0907513 52/hotel-hotel-di-daerah-gerhana-matahari-habisdipesan

Fabian, P., Winterhalter, M., \& et al. (2001). The BAYSOFI Campaign-Measurments carried out during the total solar eclipse of August 11, 1999. Meteorologische Zeitschrift, 165-170.

Foken, T., Wichura, B., \& et al. (2001). Micrometeorological measurements during the total solar eclipse of August 11, 1999. Meteorologische Zeitschrift, 171-178.

Keeler, W. (1988). Sharp rays: Javanese responses to a solar eclipse. Indonesia, 91-101.

Nishanth, T., Ojha, N., \& et al. (2011). Influence of solar eclipse of 15 January 2010 on surface ozone. Atmospheric environment, 1752-1758. 
Statistik, B. P. (2016). Perkembangan Pariwisata dan Transportasi Nasional Februari 2016. Jakarta: Badan Pusat Statistik.

Tiwari, N. K. (2015). Eclipse. International Journal of Sanskrit Research, 38-40.

Vivasumsel, R. (2016, March 8). Sumsel. Retrieved from vivasumsel.com:

http://vivasumsel.com/2016/03/08/inilah-susunanacara-festival-gmt-2016-di-sumsel/

Wirahmihardja, S. D. (2014). Ethnoastronomy: The Sundanese of West Java and their Relation to Ethnoastronomy. Kyoto: Center if Southeast Asian Studies Newsletter.

XE Currency Charts (USD/IDR). (2016, March). Retrieved from XE Web site: http://www.xe.com 